\title{
Családi és iskolai környezeti hatások érvényesülése az önszabályozott tanulás müködésében
}

\section{Napjainkban jellemzóen sikerorientált megközelítés tapasztalható a} tanulók iskolai elömenetelét illetốen. A családi elvárások összhangban vannak azon iskolai elvárásokkal, amelyek a tanulók részéról érett, meggondolt magatartást, sikeres és önálló tanulást, képességeik és tudásuk hatékony kiaknázását tartják szem elótt. Ezzel párhuzamosan a pedagógiai kutatások hasonló területeken mozognak, a hatékony iskolai tanulás kérdése mindig is a kutatások középpontját képezte. Az utóbbi idókben egyre többen hivják fel a figyelmet az önszabályozás és az iskolai sikeresség összefonódására a korai fejlesztések kapcsán (ld. Blair, 2002; Allan, Allan, Lernera, Farringtona és Lonigana, 2015). Kimutatták, hogy azok a gyerekek, akik óvodás korukban képesek érzelmeik és viselkedésük önszabályozására, könnyebben boldogulnak az iskolai kihívásokkal (Blair és Razza,2007; Kochanska, Murray és Harlan, 2000). Ez elórevetíti az önszabályozott tanulás kutatásának fontosságát, a fejlódését befolyásoló tényezók minél alaposabb megismerését.

A z önszabályozott tanulás az egyik korai definíció alapján olyan folyamatként értelmezhetö, amelyben a tanulók metakognitív, motivációs és stratégiai szempontból aktívak (Zimmerman, 2000). Ahhoz tehát, hogy magas szinten múködjön a tanulás önszabályozása, metakognitív kontroll, motivációs meggyőződések és hatékony tanulási stratégiák integrált alkalmazása szükséges (Perry, Thauberger és Hutchinson, 2010). A metakogníció magában foglalja a saját tudásunkról való tudásunkat (Csíkos, 2007), de emellett az adott feladatról való reflektív tudásunkat is, valamint azt, hogy mikor, hogyan, milyen tanulási stratégiát érdemes alkalmazni (Winne és Perry, 2000). A motivációnak mediációs szerepet szánnak az önszabályozott tanulásban (Linnebrink és Pintrich, 2001), hiszen a motívumok segítik a tanulás elkezdését, irányítják és fenntartják a tanulók erőfeszítéseit a hatékonyabb tanulás érdekében (Garcia és Pintrich, 1994). A motiváció és az önszabályozott tanulás kutatásai számos közös területtel rendelkeznek, ilyen az önhatékonyság kérdése (Pajares, 2008) vagy a célok (Dweck és Master, 2008; Fejes, 2011), illetve az érdeklődés (Hidi és Ainley, 2008) vizsgálata. A stratégiai aktivitás az alkalmazott tanulási stratégiák repertoárjára vonatkozik. A magas szinten önszabályozó tanulók hatékony tanulási stratégiákat ismernek és alkalmaznak (Butler, 2002).

Mindhárom tényező nagyon fontos, ugyanakkor önmagában egyik sem elégséges az önszabályozott tanulásban. Hiába rendelkezik egy tanuló metakognitív tudatossággal, ha nem motivált arra, hogy müködtesse ezt tanulása során (Schraw, Crippen és Hartley, 
2006). A motiváció önmagában szintén nem elégséges, ha nem társul hozzá hatékony tanulási stratégiák ismerete és tudatos alkalmazása (Whitebread és Cardenas, 2012). Számos kutatás összefüggést mutatott ki az önszabályozás képessége és a tanulmányi eredményesség között. Kimutatták, hogy azok a tanulók, akik óvodás korukban nem tudták kellően szabályozni emócióikat és impulzív viselkedésüket, az iskolai évek alatt alacsonyabb tanulási eredményeket mutattak (pl. Blair és Razza, 2007), és szociális viselkedésükben is több probléma mutatkozott (pl. Posner és Rothbart, 2000), valamint nehezebben sajátították el az iskolai szabályokat és rutinokat (Rimm-Kaufman és mtsai, 2009).

\section{Az önszabályozott tanulás és a környezet kapcsolata}

A korai értelmezések alapján az önszabályozott tanulást individuális, önálló képességként közelítették meg, melyben a tanulók egyéni képességeire, motívumaira és stratégiahasználatára fókuszáltak (Zimmerman, 1989). Ezzel párhuzamosan a szociokognitív nézőpont képviselői (pl. Bandura, 1986) az önszabályozott tanulás társas elemeit hangsúlyozták. Az utóbbi időkben egyre inkább a társas kontextus és az önszabályozás kölcsönhatását emelik ki (pl. Zimmerman, 2008), és ebben a folyamatban az önszabályozás képességének kialakulása és fejlödése nagyban függ a környezeti hatásoktól.

A környezeti hatások közül leginkább a szülök és a család befolyásoló szerepét vizsgálták. Többen is kimutatták az erőteljes szülői kontroll negatív hatását az önszabályozással összefüggésben. Blair, Calkins és Kopp (2010) kutatásai szerint a negatív kontrolláló szülöi viselkedés agresszív, túlmozgékony, nem adaptív gyermeki viselkedést vont maga után. Mások alacsony önszabályozást mutattak ki kisgyerekeknél a magas szülői vagy tanári kontroll következtében (Eisenberg, Eggum, Sallquist és Edwards, 2010). Ugyanakkor az is kiderült, hogy a szülői beavatkozás csökkenése együtt jár a kisgyerekek önszabályozó kapacitásának növekedésével, vagyis ha kellő mértékü önállóságot adnak a szülők a gyerekeknek, az elősegíti az önszabályozás fejlődését (Blair és mtsai, 2010).

Higgins és Silberman (1998) a szülök negatív, illetve pozitív szabályozásának hatását vizsgálták a kisgyerekek szociális alkalmazkodásával kapcsolatosan. A negatív szabályozás a gyerek viselkedésében csak a rossz tényezőket emeli ki, míg a pozitív szabályozás során a környezet részéről inkább a gyerek sikereinek, erösségeinek kiemelése történik. A szerzők kimutatták, hogy a pozitív szülői szabályozás jobban segíti a gyerekek szociális alkalmazkodását, a megfelelö önértékelést és az önszabályozást. Ehhez hasonlóan Jennings és munkatársai (2008) csecsemők önszabályozását vizsgálták az anyjuk viselkedésének hatásaként. Eredményeik szerint az anya viselkedése (melegséget áraszt-e, depressziós vagy szorongós) meghatározza a kisgyerekek önszabályozását. A meleg anyai viselkedés, a bátorítás, a pozitív visszajelzés a kisgyerekekben a tudatosság érzetét erösítik, könnyebben vallják magukénak a mikrokörnyezet céljait, motiváltabbak a viselkedésük szabályozására is. Tyson (2004) kimutatta, hogy ezen feltételek hiányában, a hideg, érzéketlen anyai viselkedés következményeként a kisgyerekek (3-5 évesek) nem képesek vágyaik késleltetésére, érzelmeik kontrollálására és szabályozására, nem tudták összekapcsolni viselkedésüket a következményekkel. Egyetlen szabályozási utat ismertek, a környezetüket próbálták meg viselkedésükkel befolyásolni, és ha nem teljesült az akaratuk, dühösek lettek, sírással és agresszíven reagáltak.

Nagy József (2000) is kitér a szülők, a szociális mikroközeg fontos szerepére a gyerekek önállóságának segítésében. Meglátása szerint akkor, ha a szülők infantilizálják a gyermeket, és a megfelelö fejlődési fázisban nem engedik önállósulási vágyának kibontakozását, a későbbiekben súlyos leválási problémák, konfliktusok adódhatnak, amelyek antiszociális viselkedést idézhetnek elő. Sem a gyerekek túlzott magára hagyása, sem a túlzott féltés, kiszolgálás a szülők részéről nem segíti a gyerekek önállóságát, egyénisé- 
gük kibontakozását. Ehhez az elképzeléshez illeszkedik Grolnick (2009) elmélete, aki a hatékony önszabályozás kialakulásában szerepet játszó szülői viselkedés három alapvető tényezőjét emelte ki: (1) az önállóság segítése, (2) a következetes, strukturált viselkedés, illetve (3) az aktív részvétel a gyerek életében. Ezek azok a korai szülöi hatások, amelyek révén az önszabályozás megfelelö ütemben fejlődhet.

Az egyre bővülő neurokognitív kutatások rávilágítottak a környezeti tényezők és az agyfejlődés közötti összefüggésekre. Blair és munkatársai (2010) eredményei alapján az alacsony szocio-ökonomiai státusz és a megterhelő életesemények (pl. családi traumák, válás, depresszív szülő, állandó büntetés) a stresszhormon aktiválása következtében hatással vannak a gyerek agyfejlődésére, különösen a prefrontális kéreg müködésére, ami az önszabályozásért felelős agyi terület. Evans és Schamberg (2009) kimutatták, hogy a megemelkedett kortizolszint a huzamosabb ideig fennálló stresszel együtt végérvényes hatással lesz a munkamemóriára, míg Blair és munkatársai (2011) ezek meghatározó szerepét mutatták ki a végrehajtó funkciókra és az emóciók önszabályozására. Ezek az eredmények azt jelzik, hogy azoknak a gyerekeknek, akiket huzamosabb ideig stresszhatás ér, sem munkamemóriájuk, sem végrehajtó funkcióik, ezen belül önszabályozásuk nem tud kellő mértékben fejlődni.

Az önszabályozott tanulás kapcsán Alvi és Gillies (2015) három fontos jellemzőt emelnek ki. Ebben a folyamatban a tanuló aktívan részt vesz (saját céljai vannak, hatékony tanulási és motivációs stratégiákat használ stb.) saját tanulásában, és ő maga a felelős a tanulás megvalósulásáért, kimeneteléért. Másodsorban ez a tanulás nem elszigetelten történik, hanem többnyire társas közegben, ahol a tanárok, osztálytársak hatással vannak erre a folyamatra, és ez szintén befolyásolja a tanulás irányát. Mindezek mellett a tanuló erőfeszítéseket tesz ahhoz, hogy a tanulása hatékony legyen. Ez utóbbit erőfeszítésen alapuló kontrollnak is nevezik (Rothbart és Bates, 2006).

\section{Az empirikus vizsgálat jellemzői}

\section{Célok}

Vizsgálatunkban arra kerestük a választ, hogy a rendelkezésünkre álló családi és iskolai tényezők közül melyek vannak hatással az önszabályozott tanulás müködésére, továbbá milyen összefüggések mutathatók ki az önszabályozott tanulás egyes komponensei és a környezeti tényezők között. Feltételezésünk alapján a környezeti tényezők mindenképp befolyásolják a tanulók tanulását, de éppen az önállóság (mint az önszabályozott tanulás egyik tulajdonsága) miatt ezek hatása nem egyértelmü.

\section{Minta és eljárás}

Az elemzésbe bevont mintát a Szegedi Iskolai Longitudinális Program (ld. Csapó, 2014) 4. évfolyamos tanulói alkották. A nemek aránya hasonlóan alakult, közel azonos a fiúk és a lányok száma (1. táblázat). Az átlagéletkor 10,13 év.

1. táblázat. A vizsgálatban részt vevők jellemzői

\begin{tabular}{|l|c|c|}
\hline \multicolumn{1}{|c|}{ Minta } & $N$ & Átlagéletkor \\
\hline Fiú & 2253 & 10,09 \\
\hline Lány & 2223 & 10,18 \\
\hline Összesen & 4476 & 10,13 \\
\hline
\end{tabular}


A vizsgálatot 2015 tavaszán bonyolítottuk le a programban részt vevő pedagógusok segítségével. A mérőeszközöket elektronikus úton töltötték ki a tanulók. A papír és az elektronikus alapú, affektív tényezőket vizsgáló kérdőíves módszer összehasonlítása azt mutatja, hogy nincs különbség a két mérési módszer között a kapott eredmények tekintetében (ld. Józsa, Szenczi és Hricsovinyi, 2011).

\section{Méröeszközök}

A vizsgálatban egy, az önszabályozott tanulás mérésére kidolgozott kérdőívet $(D$. Molnár, 2013), illetve egy háttérkérdöívet töltöttek ki a tanulók. Az önszabályozott tanulás kérdőíve azt vizsgálja, hogy a tanulók milyen tanulási stratégiákat használnak, illetve hogyan és mennyire motiváltak tanulásuk során. A kérdöív két fő alskálát tartalmaz: tanulási stratégiák ( 42 item, Cronbach- $\alpha=0,89$ ) és tanulási motívumok ( 46 item, Cronbach- $\alpha=0,90)$, melyekben a tanulók ötfokú Likert-skálán ítélték meg magukra vonatkozóan az egyes itemeket.

A tanulási stratégiákat három nagy csoportra bonthatjuk aszerint, hogy a megtanulandó információkat hogyan kezelik a diákok. A kognitív stratégiák alá azok az eljárások tartoznak, amikor a megtanulandó ismereteket egyrészt ismételgetéssel, többszöri elolvasással rögzítik (memorizálás), másrészt úgy rendezik el a megtanulandó anyagot (megszervezés/elaboráció), hogy azt a legkönnyebb legyen elsajátítani (pl. ábrák, leckevázlat készítése). A metakognitív stratégiák révén a tanulási folyamat kontrollálása valósul meg a tanulási idő megtervezése, a tanulási folyamat monitorozása, ellenőrzése, illetve értékelése révén (tervezés, nyomon követés, kontrollálás/szabályozás). A belső és a külső erőforrások kihasználása a harmadik nagyobb csoport, ezzel a segítségkérés és a halogatás mérhető.

A tanulási motívumokat aszerint csoportosíthatjuk, hogy mi az, ami alapján a tanulók megkezdik és fenntartják a tanulási tevékenységüket, miért tanulnak, mennyire tartják fontosnak és értéknek a tanulást, mit gondolnak magukról, mennyiben bíznak abban, hogy meg tudnak tanulni egy-egy tananyagot. Ez alapján a kérdőívben vizsgáljuk az elsajátítási motívumot (képességeinek, tudásának fejlesztése a cél), a teljesítménykereső és -kerülő motívumokat (elöbbi az eredményért, jegyekért, elismerésért tanul, utóbbi a rossz eredmény, jegy elkerüléséért), a szorongást, a pozitív és negatív önhatékonyságot (mennyire hisz képességeiben, saját hatékonyságában). Mindezek mellett az amotiváció is része a kérdőív legújabb változatának, ami az általános motiválatlanságot, a tanulás elkerülését tárja fel (ld. D. Molnár, 2013).

A háttérkérdőívben a tanulók személyes adatai (nem, életkor, osztály ismétlése) mellett a szülők iskolai végzettségére, valamint a család gazdasági hátterére vonatkozó itemek is szerepeltek. Több változó is vizsgálta az otthoni tanulást segítő szülői magatartást, valamint az otthoni és iskolai kiegészítő foglalkozások (korrepetálás, tehetségprogramban, sportkörön való foglalkozás) megjelenését. A kérdések között egyaránt szerepelt Likert-skálás (négyfokú) és dichotóm (igen, nem) megfogalmazású is. 


\section{Eredmények}

\section{Nem szerinti különbségek a tanulási motívumok fejlettségében és a stratégiahasználatban}

Az önszabályozott tanulás komponensei kapcsán eltérő eredményekről számol be a szakirodalom, többségében a lányok magasabb szintü belső tanulási motívumairól (pl. Soric, 2009), valamint a fiúk magasabb szintü önhatékonyságáról, pozitívabb attribúcióiról (pl. Deci és Moller, 2007). A tanulási motívumok fejlettsége esetében mintánkban csupán négy esetben találtunk szignifikáns különbséget (2. táblázat). Ez alapján a fiúk teljesítménykereső és teljesítménykerülő motívumai fejlettebbek, mint a lányoké, ugyanakkor a negatív önhatékonyság és az általános motiválatlanság is jobban jellemző rájuk, mint a lányokra. Ez azt jelenti, hogy a fiúk jobban törekednek a jó jegyek és az eredmények elérésére, mint a lányok, de az is jobban jellemző rájuk, hogy tanulásuk során a rossz jegyek elkerülésére törekednek. Gyakrabban vetítik előre a tanulásuk negatív végkifejletét, és gyakrabban vallják magukat inkompetensnek a tanulás terén, mint a lányok. Az elsajátítási motívum, a pozitív önhatékonyság és a szorongás kapcsán nincs szignifikáns eltérés.

2. táblázat. A tanulási motívumok fejlettsége nem szerinti bontásban

\begin{tabular}{|c|c|c|c|c|c|c|}
\hline Motívumok & $\mathrm{Nem}$ & $N$ & Átlag & Szórás & $t$ & $p$ \\
\hline \multirow{2}{*}{ Elsajátítási motívum } & fiú & 1732 & 74,80 & 17,10 & \multirow{2}{*}{$-2,69$} & \multirow{2}{*}{ n.s. } \\
\hline & lány & 1798 & 76,32 & 16,69 & & \\
\hline \multirow{2}{*}{ Teljesítménykereső motívum } & fiú & 2008 & 68,16 & 22,54 & \multirow{2}{*}{6,68} & \multirow{2}{*}{0,00} \\
\hline & lány & 2051 & 63,40 & 22,88 & & \\
\hline \multirow{2}{*}{ Teljesítménykerülő motiváció } & fiú & 1991 & 56,45 & 22,80 & \multirow{2}{*}{7,06} & \multirow{2}{*}{0,00} \\
\hline & lány & 2023 & 51,45 & 22,05 & & \\
\hline \multirow{2}{*}{ Szorongás } & fiú & 1955 & 48,40 & 23,58 & \multirow{2}{*}{$-1,18$} & \multirow{2}{*}{ n.s. } \\
\hline & lány & 2024 & 49,29 & 23,56 & & \\
\hline \multirow{2}{*}{ Pozitív önhatékonyság } & fiú & 2113 & 65,64 & 24,91 & \multirow{2}{*}{1,45} & \multirow{2}{*}{ n.s. } \\
\hline & lány & 2140 & 64,54 & 24,79 & & \\
\hline \multirow{2}{*}{ Negatív önhatékonyság } & fiú & 1999 & 32,98 & 17,82 & \multirow{2}{*}{4,60} & \multirow{2}{*}{0,00} \\
\hline & lány & 2027 & 30,57 & 15,38 & & \\
\hline \multirow{2}{*}{ Amotiváció } & fiú & 2136 & 46,97 & 28,55 & \multirow{2}{*}{427} & \multirow{2}{*}{0,00} \\
\hline & lány & 2138 & 40,58 & 25,87 & & \\
\hline
\end{tabular}

Megjegyzés: n.s. =nem szignifikáns

Az egyes motívumok fejlettsége kapcsán hasonló tendenciák rajzolódnak ki mindkét minta esetében. A fiúk és a lányok egyaránt az elsajátítási motívumot tekintik a legfejlettebbnek, a legalacsonyabbnak pedig a negatív önhatékonyságot. Ez azt jelenti, hogy mindkét csoport a tanulás során leginkább arra törekszik, hogy megértse a tananyagot és képességeit fejlessze, ugyanakkor kevésbé vetítik előre a negatív következményeket, kevésbé jellemző rájuk a negatív önértékelés. Más nagymintás mérésünkben hasonló mintázatot mutatott az egyes motívumok fejlettsége; a vizsgált évfolyamok mindegyikén az elsajátítási motívum adódott a legfejlettebbnek, míg a szorongás és a negatív önhatékonyság mutatta a legalacsonyabb értékeket (D. Molnár, 2013).

A tanulási stratégiák esetében több szignifikáns különbség is kimutatható (csupán a tervezés esetében nincs jelentős különbség, ld. 3. táblázat). Ezek szerint a lányokra a legtöbb tanulási stratégia használata jellemzőbb, mint a fiúkra, kivéve a halogatást. A halo- 
gatás tekintetében a fiúk rendelkeznek magasabb értékkel, ami arra utal, hogy gyakrabban halogatnak tanulásuk során, mint a lányok. Az egyes stratégiák használata között nem rajzolódik ki jelentős különbség, a halogatás kivételével (ami a legalacsonyabb értéket mutatja) hasonló szinten (50-50 százalékpont körül) alkalmazzák mindegyiket a tanulók nemtől függetlenül.

3. táblázat. A tanulási stratégiák használatának jellemzői nemek szerinti bontásban

\begin{tabular}{|c|c|c|c|c|c|c|}
\hline Tanulási stratégiák & $\mathrm{Nem}$ & $N$ & Átlag & Szórás & $t$ & $p$ \\
\hline \multirow{2}{*}{ Memorizálás } & fiú & 1988 & 59,94 & 22,56 & \multirow{2}{*}{$-7,12$} & \multirow{2}{*}{0,00} \\
\hline & lány & 2012 & 64,88 & 21,32 & & \\
\hline \multirow{2}{*}{ Megszervezés/Elaboráció } & fiú & 1959 & 47,40 & 21,26 & \multirow{2}{*}{$-3,84$} & \multirow{2}{*}{0,00} \\
\hline & lány & 1981 & 50,04 & 21,84 & & \\
\hline \multirow{2}{*}{ Tervezés } & fiú & 2052 & 57,33 & 21,65 & \multirow{2}{*}{$-1,58$} & \multirow{2}{*}{ n.s. } \\
\hline & lány & 2060 & 58,38 & 20,85 & & \\
\hline \multirow{2}{*}{ Nyomon követés } & fiú & 2039 & 63,87 & 20,92 & \multirow{2}{*}{$-6,31$} & \multirow{2}{*}{0,00} \\
\hline & lány & 2057 & 67,91 & 19,98 & & \\
\hline \multirow{2}{*}{ Kontrollálás/Szabályozás } & fiú & 1865 & 65,57 & 16,46 & \multirow{2}{*}{$-6,75$} & \multirow{2}{*}{0,00} \\
\hline & lány & 1895 & 69,12 & 15,83 & & \\
\hline \multirow{2}{*}{ Segítségkérés } & fiú & 2072 & 60,75 & 25,40 & \multirow{2}{*}{$-8,47$} & \multirow{2}{*}{0,00} \\
\hline & lány & 2087 & 67,16 & 23,39 & & \\
\hline \multirow{2}{*}{ Halogatás } & fiú & 2095 & 32,04 & 18,62 & \multirow{2}{*}{5,70} & \multirow{2}{*}{0,00} \\
\hline & lány & 2092 & 28,98 & 16,07 & & \\
\hline
\end{tabular}

Megjegyzés: n.s. $=$ nem szignifikáns

A nemek szerinti különbségek kimutatása kapcsán egyéb háttérváltozók összefüggő hatását is ellenőriztük. Ez alapján kiderült, hogy a fiúkkal szignifikánsan többet foglalkozik gyógypedagógus és fejlesztő pedagógus $(\mathrm{m}=1,82)$, mint a lányokkal $(\mathrm{m}=1,89, \mathrm{p}=0,00)$. Ugyanakkor a fiúk csoportjára jellemzőbb $(\mathrm{m}=1,47)$ az iskolai sportköri foglalkozásokon való részvétel, mint a lányokra $(\mathrm{m}=1,59 \mathrm{p}=0,00)$. A későbbiekben ezen iskolai tevékenységek összefüggéseit a tanulási motívumokkal és stratégiákkal részletesebben elemezzük.

\section{Az otthoni, szülöi gondoskodás összefüggései az önszabályozott tanulás komponenseivel}

Az otthoni segítség formáját öt itemen keresztül vizsgáltuk: „otthon segítenek a tanulásban”, „otthon gyakorolnak velem”, „otthon kikérdezik a leckét”, „otthon megbeszéljük az iskolában történteket”, valamint „,segítség nélkül tanulok” egy négyfokú Likert-skálán (1 - soha, 4 - szinte mindig). Ezek a változók az egyes motívumokkal többnyire szignifikáns, de nem erős kapcsolatokat mutattak (4. táblázat).

Az elsajátítási motívummal mutat szorosabb összefüggést az, ha otthon megbeszélik az iskolában történteket. Ezen kívül a pozitív önhatékonysággal legszorosabban a segítség nélküli tanulás függ össze, vagyis azok a tanulók, akik önállóan tanulnak, jobban bíznak képességeikben, és fordítva, akik magasabb önhatékonysággal rendelkeznek, gyakrabban tanulnak otthon egyedül. Ugyanakkor negatívan hat az önhatékonyságra az, ha otthon segítséget kapnak a tanuláshoz $(\mathrm{r}=-0,15, \mathrm{p}=0,01)$, valamint ha gyakorolnak velük a szülők $(r=-0,08, p=0,01)$. Mindemellett a segítség nélküli tanulás szintén szignifi- 
káns, tendencia jellegü összefüggést mutat a szorongással és a negatív önhatékonysággal. Ez azt jelenti, hogy azon tanulók esetében, akiket szorongással tölt el a tanulás, valamint nem bíznak eléggé képességeikben, az önálló, segítség nélküli tanulás felerősíti ezeket a motívumokat. Az ő esetükben az otthoni szülői segítség megnyugtató lehet $(r=0,13$, $\mathrm{p}=0,01)$.

4. táblázat. Az otthoni segitség összefüggése a motivumok fejlettségével és a stratégiákkal

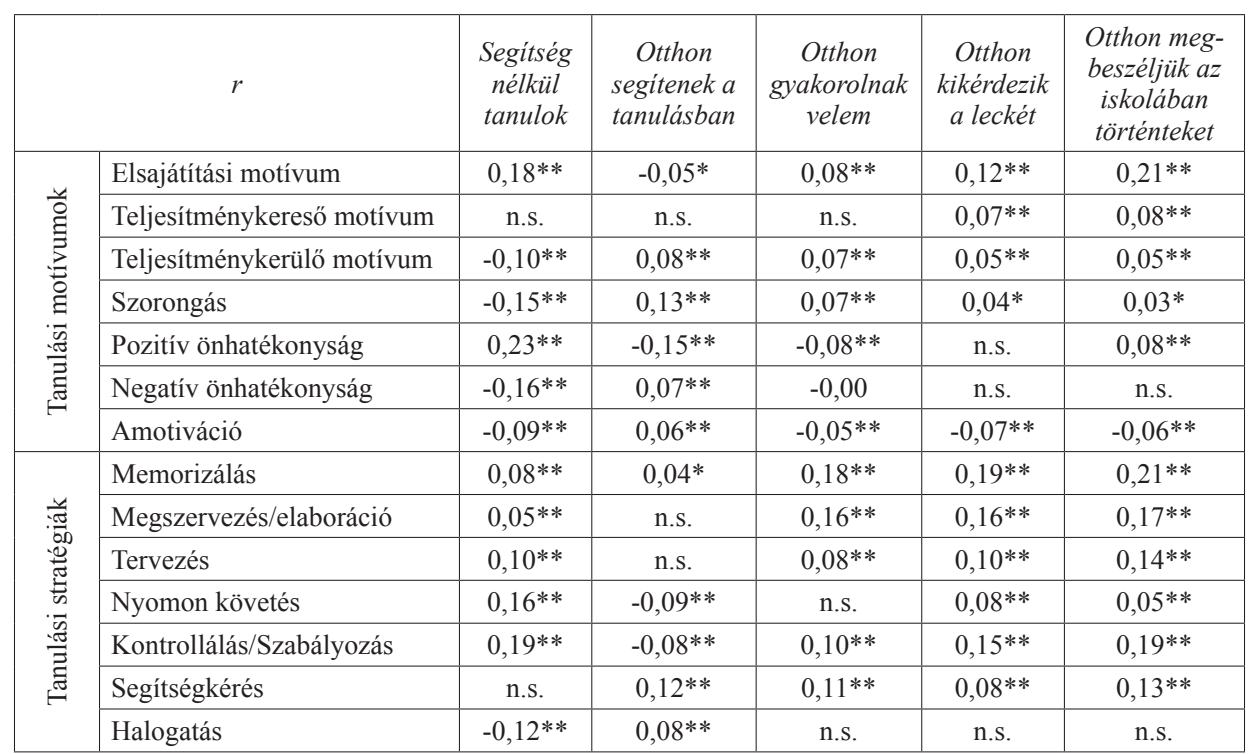

Megjegyzés: $* * p=0,01 ; * p=0,05 ;$ n.s. $=$ nem szignifikáns

A tanulási stratégiák esetében hasonlóan szignifikáns, de föként tendencia jellegü összefüggéseket találtunk az otthoni segítség változóival. Összességében az iskolai történetek otthoni megbeszélése jár együtt a legtöbb tanulási stratégiával, ami azt mutatja, hogy azok a diákok, akik gyakrabban beszélik meg otthon az iskolai eseményeket, magasabb szinten használják ezeket a stratégiákat. Külön figyelmet érdemelnek a metakognitív stratégiák (nyomon követés, kontrollálás/szabályozás), amelyek müködtetése az önálló, segítség nélküli tanulással pozitív összefüggéseket mutat, míg az otthoni, szülöi segítség éppen ezen stratégiák csökkenéséhez vezet.

A további összefüggések feltárására az otthoni segítség változóit dichotóm változókká alakítottuk ( $1=$ nem, ritkán; $2=$ igen, gyakran). Azt vizsgáltuk, hogy azok a tanulók, akik kapnak otthoni támogatást a tanulásukhoz, milyen motívumokkal és milyen stratégiahasználattal jellemezhetők. Szinte minden esetben szignifikánsan elkülönülö csoportokat kaptunk aszerint, hogy támogatják otthon vagy sem a tanulásukat. Ezek közül csak azokat az összefüggéseket mutatjuk be táblázatos formában, amelyek a legtöbb motívumban és stratégiahasználatban eltérést mutattak a két csoport között.

A segítség nélküli tanulás - a segítségkérés és a megszervezés stratégiákat kivéve - az összes többi stratégia esetében szignifikáns különbségeket mutatott. Ezek szerint azok, akik önállóan tanulnak (minden esetben $\mathrm{p}=0,00$ ), magasabb szinten használják a memorizálás ( $m=63$ százalékpont), a tervezés ( $m=60$ százalékpont), a nyomon követés $(m=69$ százalékpont) és kontrollálás $(m=70$ százalékpont) stratégiákat, ugyanakkor kevésbé halogatnak ( $\mathrm{m}=28$ százalékpont), mint azok, akikre nem jellemző az önálló tanulás. 
A motívumok kapcsán a teljesítménykereső motívum kivételével minden esetben szignifikánsan elkülönül a két csoport aszerint, hogy segítség nélkül tanulnak-e vagy sem. Ez alapján az önállóan tanulók (minden esetben $\mathrm{p}=0,00$ ) magasabb elsajátítási motívummal ( $m=78$ százalékpont) és pozitív önhatékonysággal ( $m=69$ százalékpont) rendelkeznek, ugyanakkor alacsonyabb szintü a teljesítménykerülő motívumuk ( $\mathrm{m}=52$ százalékpont), negatív önhatékonyságuk ( $\mathrm{m}=29$ százalékpont) és szorongásuk ( $\mathrm{m}=46$ százalékpont), mint azoknak, akik nem önállóan tanulnak. Az eredmények azt mutatják, hogy a segítség nélkül tanulóknak fejlettebbek a pozitív motívumaik (a tananyag elsajátítására, megértésére, képességeik fejlesztésére törekednek, valamint jobban bíznak saját képességeikben), mint azok, akik segítséggel tanulnak. Ugyanakkor az alacsonyabb szintü negatív motívumaik (nem szoronganak annyira, nem jellemző rájuk a negatív önhatékonyság és a teljesítmény elkerülése) a tanulásukban kevésbé játszanak befolyásoló szerepet, mint társaik esetében, akik gyakrabban tanulnak segítséggel.

Az otthoni, szülöi gondoskodás változói közül az „otthon kikérdezik a leckét” item mutat minden tanulási stratégia esetében szignifikánsan elkülönülő értékeket a két csoport között (5. táblázat). Az eredmények tehát azt mutatják, hogy amennyiben a szülők otthon kikérdezik a megtanult tananyagot, az pozitívan befolyásolja a tanulási stratégiák használatát. Azok a tanulók, akiknek szüleik segítenek az otthoni kikérdezéssel, magasabb szinten használják a memorizálás, tervezés, nyomon követés, szabályozás stratégiákat, bátrabban kérnek segítséget, ha elakadnak a tanulásukban, ugyanakkor kevésbé halogatnak, mint azok, akiknek otthon nem kérdezik ki a leckét.

5. táblázat. Tanulási stratégiák használata az otthoni leckekikérdezés alapján elkülönülö csoportokban

\begin{tabular}{|c|c|c|c|c|c|c|}
\hline Tanulási stratégiák & $\begin{array}{c}\text { Otthon kikérdezik } \\
\text { a leckét }\end{array}$ & $N$ & Átlag & Szórás & $t$ & $p$ \\
\hline \multirow{2}{*}{ Memorizálás } & Nem, ritkán & 1039 & 56,41 & 22,80 & \multirow{2}{*}{$-10,21$} & \multirow{2}{*}{0,00} \\
\hline & Igen, gyakran & 2553 & 64,60 & 21,42 & & \\
\hline \multirow{2}{*}{ Megszervezés/elaboráció } & Nem, ritkán & 1024 & 43,91 & 21,03 & \multirow{2}{*}{$-8,33$} & \multirow{2}{*}{0,00} \\
\hline & Igen, gyakran & 2505 & 50,53 & 21,57 & & \\
\hline \multirow{2}{*}{ Tervezés } & Nem, ritkán & 1067 & 54,96 & 21,55 & \multirow{2}{*}{$-5,16$} & \multirow{2}{*}{0,00} \\
\hline & Igen, gyakran & 2609 & 58,94 & 21,08 & & \\
\hline \multirow{2}{*}{ Nyomon követés } & Nem, ritkán & 1074 & 64,26 & 21,72 & \multirow{2}{*}{$-3,91$} & \multirow{2}{*}{0,00} \\
\hline & Igen, gyakran & 2606 & 67,13 & 19,64 & & \\
\hline \multirow{2}{*}{ Kontrollálás/Szabályozás } & Nem, ritkán & 970 & 64,29 & 16,76 & \multirow{2}{*}{$-7,10$} & \multirow{2}{*}{0,00} \\
\hline & Igen, gyakran & 2393 & 68,63 & 15,79 & & \\
\hline \multirow{2}{*}{ Segítségkérés } & Nem, ritkán & 1093 & 61,42 & 24,79 & \multirow{2}{*}{$-3,98$} & \multirow{2}{*}{0,00} \\
\hline & Igen, gyakran & 2631 & 64,93 & 24,44 & & \\
\hline \multirow{2}{*}{ Halogatás } & Nem, ritkán & 1101 & 31,36 & 17,63 & \multirow{2}{*}{2,43} & \multirow{2}{*}{0,02} \\
\hline & Igen, gyakran & 2646 & 29,86 & 17,11 & & \\
\hline
\end{tabular}

A stratégiák kapcsán egy másik változó (az „otthon megbeszéljük az iskolában történteket") mutat még szignifikánsan elkülönülö értékeket a két csoport között. A halogatás kivételével (ez esetben nincs szignifikáns különbség) minden stratégia kapcsán magasabb értékeket mutatnak azok a tanulók, akik otthon megbeszélik az iskolában történteket. Ez szintén azt jelzi, hogy az otthoni (közvetett) támogatás pozitívan összefügg a tanulási stratégiák használatával. Ugyanígy müködik az „otthon gyakorolnak velem” item, ami a monitorozás és halogatás stratégiák kivételével minden más esetben szig- 
nifikánsan elkülönülő csoportokat eredményezett. Így azok a tanulók, akikkel otthon gyakorolnak, gyakrabban használják a memorizálás, a tervezés, az elrendezés, valamint a szabályozás stratégiákat, mint azok, akikkel nem vagy csak ritkán gyakorolnak otthon.

A tanulási motívumok fejlettsége kapcsán az otthoni támogatás változói közül az „otthon segítenek a tanulásban” item mutat szignifikánsan elkülönülő értékeket a két csoport esetében (1. ábra). A teljesítménykereső motívum kivételével minden esetben szignifikáns különbséget találtunk a két csoport (akiknek segítenek otthon a tanulásban, és akiknek nem) között.

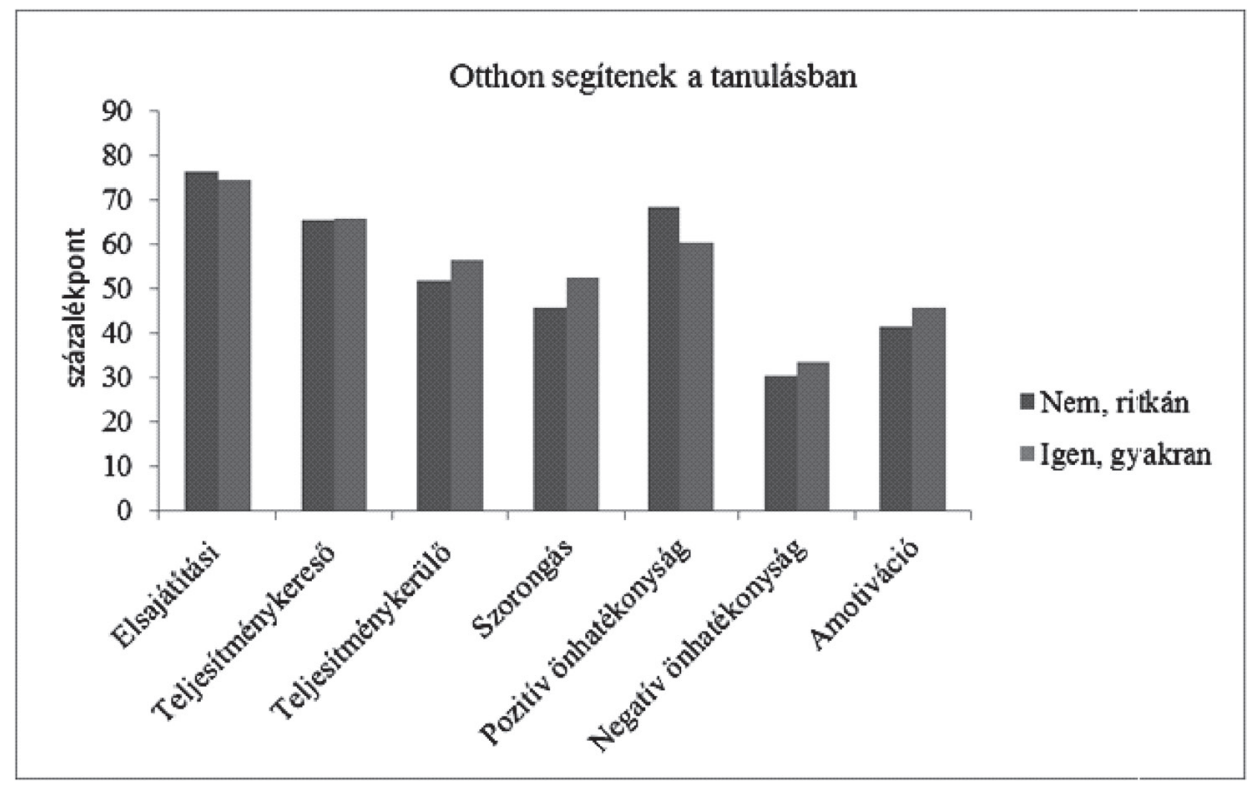

1. ábra. „,Otthon segitenek a tanulásban”- szignifikánsan elkülönülö értékek

Ugyanakkor nem olyan egyértelmü tendenciát láthatunk, mint a stratégiahasználat esetében. Míg azok a gyerekek, akiknek otthon segítenek a tanulásban, elsajátítási motívumukban és pozitív önhatékonyságukban egyaránt alacsonyabb értékeket mutatnak, mint azok, akiknek otthon nem segítenek a tanulásban, addig a szorongás, a negatív önhatékonyság, valamint az általános motiválatlanság terén szignifikánsan magasabb értékekkel rendelkeznek. Ez arra enged következtetni, hogy a tanulók az otthoni segítségnyújtást úgy élik meg, mint akik nem elég kompetensek a tanulás terén. Ezért lehet az, hogy kevésbé bíznak saját képességeikben, jobban szoronganak, és jobban előrevetítik tanulásuk negatív kimenetelét, mint azok a tanulók, akik nem kapnak segítséget az otthoni tanulásukban. A fentebb, részletesebben ismertetett önálló, segítség nélküli tanulás változója kapcsán kapott eredmények alátámaszthatják ezt az eredményt, miszerint éppen a segítség nélküli tanulással jár együtt a magasabb szintü önértékelés és pozitív önhatékonyság. 


\section{Iskolai tényezők összefüggései a tanulási motívumokkal és stratégiahasználattal}

Az iskolai tényezőkhöz soroltuk az évismétléssel, valamint az iskola keretén belül müködő tanítói, gyógypedagógusi külön foglalkozásokkal és sportfoglalkozásokkal kapcsolatos összefüggéseket. Az évismétlések közül (1., 2. vagy 3. osztályt ismételte-e) a 3. osztály ismétlése kapcsán találtunk szorosabb összefüggéseket a tanulás egyes komponenseivel, ezért csak ezekre az összefüggésekre világítunk rá.

Az eredmények azt mutatják, hogy a 3. osztályt ismételtek 15 százaléka fiú, 10 százaléka lány, és a szülők iskolai végzettségét is figyelembe véve megállapítható, hogy az osztályismétlők 50 százaléka általános iskolát végzett vagy be nem fejezett, valamint szakmunkásképző végzettséggel rendelkező szülői háttérrel rendelkezik, ugyanakkor 22 százalékuk felsőfokú végzettséggel rendelkező szülők gyereke. Ezek az arányok is azt mutatják, hogy a szülők iskolai végzettsége és az osztályismétlés közötti összefüggés tendenciaszerü $(\mathrm{r}=0,18, \mathrm{p}=0,01)$. Megvizsgálva a 3. osztályt ismételt és nem ismételt csoport gazdaságitőke- és lakhatási körülményeinek szintjét, nem találtunk jelentős különbséget a két csoport között. Ugyanakkor az évet ismételtek és nem ismételtek eltérö motívumfejlettséggel rendelkeznek (6. táblázat).

6. táblázat. Tanulási motívumok fejlettsége az évismétlés alapján elkülönülö csoportoknál

\begin{tabular}{|c|c|c|c|c|c|c|}
\hline Motívumok & $\begin{array}{l}\text { 3. osztály } \\
\text { ismétlése }\end{array}$ & $N$ & Átlag & Szórás & $t$ & $p$ \\
\hline \multirow{2}{*}{ Elsajátítási motívum } & igen & 407 & 72,27 & 18,69 & \multirow{2}{*}{$-4,30$} & \multirow{2}{*}{0,00} \\
\hline & nem & 2704 & 76,12 & 16,48 & & \\
\hline \multirow{2}{*}{ Teljesítménykereső motívum } & igen & 498 & 66,50 & 22,30 & \multirow{2}{*}{1,15} & \multirow{2}{*}{ n.s. } \\
\hline & nem & 3058 & 65,22 & 22,94 & & \\
\hline \multirow{2}{*}{ Teljesítménykerülő motívum } & igen & 494 & 58,40 & 21,92 & \multirow{2}{*}{5,42} & \multirow{2}{*}{0,00} \\
\hline & nem & 3027 & 52,49 & 22,52 & & \\
\hline \multirow{2}{*}{ Szorongás } & igen & 481 & 53,94 & 23,17 & \multirow{2}{*}{5,72} & \multirow{2}{*}{0,00} \\
\hline & nem & 3011 & 47,37 & 23,42 & & \\
\hline \multirow{2}{*}{ Pozitív önhatékonyság } & igen & 537 & 59,12 & 26,11 & \multirow{2}{*}{$-6,00$} & \multirow{2}{*}{0,00} \\
\hline & nem & 3173 & 66,07 & 24,56 & & \\
\hline \multirow{2}{*}{ Negatív önhatékonyság } & igen & 498 & 35,99 & 18,64 & \multirow{2}{*}{6,79} & \multirow{2}{*}{0,00} \\
\hline & nem & 3041 & 30,63 & 15,93 & & \\
\hline \multirow{2}{*}{ Amotiváció } & igen & 539 & 48,45 & 27,76 & \multirow{2}{*}{4,77} & \multirow{2}{*}{0,00} \\
\hline & nem & 3199 & 42,40 & 27,14 & & \\
\hline
\end{tabular}

Megjegyzés: n.s. =nem szignifikáns

A teljesítménykereső motívum kivételével minden motívum kapcsán szignifikáns különbség található az évismétlés szempontjából elkülönülö két csoport között (6. táblázat). Míg azok, akik nem ismételték a 3. osztályt, magasabb elsajátítási motívummal és pozitív önhatékonysággal rendelkeznek, a többi, negatív elöjelű motívum terén (teljesítménykerülés, szorongás, negatív önhatékonyság, amotiváció) alacsonyabb értékeket mutatnak, mint évet ismételt társaik. Ez azt jelenti, hogy magabiztosabbak, jobban törekednek a készségeik, képességeik fejlesztésére, a tananyag elsajátítására, ugyanakkor kevésbé szoronganak tanulási szituációkban, kevésbé jellemző rájuk az általános motiválatlanság, a negatív önértékelés, mint azokra, akik a 3. osztályt ismételték.

A tanulási stratégiák használatában szintén találhatunk különbséget az évismétlés szempontjából elkülönülő két csoport között (7. táblázat). Míg a metakognitív stratégi- 
ák (nyomon követés, kontrollálás/szabályozás) esetében azok, akik nem ismételtek évet, szignifikánsan magasabb értékekkel rendelkeznek, a megszervezés és halogatás kapcsán alacsonyabb értékeket mutatnak, mint osztályismétlő társaik. Ez azt jelenti, hogy azok, akik évet ismételtek, tanulásukban kevésbé alkalmazzák a szabályozó, kontrolláló és monitorozó stratégiákat, de jobban törekednek a tananyag elrendezésére, olyanná alakítására, ami könnyebbé teszi az elsajátítást, ugyanakkor gyakrabban is halogatnak, mint azok, akik nem ismételtek évet.

7. táblázat. Tanulási stratégiák használata az évismétlés alapján elkülönülö csoportoknál

\begin{tabular}{|c|c|c|c|c|c|c|}
\hline Tanulási stratégiák & 3. osztály ismétlése & $N$ & Átlag & Szórás & $t$ & $p$ \\
\hline \multirow{2}{*}{ Memorizálás } & igen & 493 & 61,02 & 21,58 & \multirow{2}{*}{$-1,25$} & \multirow{2}{*}{ n.s. } \\
\hline & nem & 3017 & 62,36 & 22,14 & & \\
\hline \multirow{2}{*}{ Megszervezés/elaboráció } & igen & 487 & 51,96 & 21,50 & \multirow{2}{*}{3,98} & \multirow{2}{*}{0,00} \\
\hline & nem & 2964 & 47,77 & 21,53 & & \\
\hline \multirow{2}{*}{ Tervezés } & igen & 503 & 56,83 & 20,88 & \multirow{2}{*}{$-1,04$} & \multirow{2}{*}{ n.s. } \\
\hline & nem & 3090 & 57,90 & 21,29 & & \\
\hline \multirow{2}{*}{ Nyomon követés } & igen & 512 & 62,49 & 21,14 & \multirow{2}{*}{$-4,54$} & \multirow{2}{*}{0,00} \\
\hline & nem & 3083 & 66,90 & 20,20 & & \\
\hline \multirow{2}{*}{ Kontrollálás/Szabályozás } & igen & 432 & 65,00 & 16,64 & \multirow{2}{*}{$-3,27$} & \multirow{2}{*}{0,00} \\
\hline & nem & 2866 & 67,73 & 16,07 & & \\
\hline \multirow{2}{*}{ Segítségkérés } & igen & 516 & 62,37 & 24,82 & \multirow{2}{*}{$-1,50$} & \multirow{2}{*}{ n.s. } \\
\hline & nem & 3123 & 64,11 & 24,38 & & \\
\hline \multirow{2}{*}{ Halogatás } & igen & 513 & 33,76 & 18,57 & \multirow{2}{*}{4,97} & \multirow{2}{*}{0,00} \\
\hline & nem & 3145 & 29,66 & 17,13 & & \\
\hline
\end{tabular}

Megjegyzés: $n . s .=$ nem szignifikáns

Az iskolai, környezeti hatások kapcsán megvizsgáltuk egyrészt azt, hogy a korrepetálásra (gyógypedagógushoz vagy tanítóhoz) járás alapján van-e különbség a tanulási motívumok fejlettsége és a tanulási stratégiák használata tekintetében. Másrészt azt is ellenőriztük, hogy az iskolai tehetséggondozó programokon, valamint sportköri foglalkozásokon való részvétel hogyan befolyásolja a motívumok és stratégiák használatát.

Az eredmények azt mutatják, hogy akiket nem korrepetál a tanítójuk, azok rendre magasabb értékeket mutatnak az egyes stratégiák használatában (tervezés: $m=59$ százalékpont $>m=54$ százalékpont; nyomon követés: $m=68$ százalékpont $>m=56$ százalékpont; szabályozás: $m=69$ százalékpont $>\mathrm{m}=60$ százalékpont; minden esetben $\mathrm{p}=0,00$ ), mint azok, akik korrepetálásra járnak. Ugyanakkor az utóbbi csoport esetében a halogatás $(\mathrm{m}=39$ százalékpont $>\mathrm{m}=29$ százalékpont; $\mathrm{p}=0,00)$ gyakrabban megjelenik.

A tanítói korrepetálás alapján elkülönülö csoportok a motívumok terén szintén szignifikánsan különböző értékeket mutatnak (minden esetben $\mathrm{p}=0,00$ ). Akik korrepetálásra járnak, a pozitív motívumok terén alacsonyabb (elsajátítási: $\mathrm{m}=68$ százalékpont $<\mathrm{m}=77$ százalékpont; pozitív önhatékonyság: $\mathrm{m}=51$ százalékpont $<\mathrm{m}=68$ százalékpont) értékeket mutatnak. Ugyanakkor náluk a negatív motívumok esetében magasabb (teljesítménykerülő: $m=61$ százalékpont $>m=52$ százalékpont, szorongás: $m=58$ százalékpont $>$ $m=47$ százalékpont, negatív önhatékonyság: $m=42$ százalékpont $>m=30$ százalékpont, amotiváció: $\mathrm{m}=51$ százalékpont $>\mathrm{m}=42$ százalékpont) értékek jelentkeztek.

A tehetséggondozói programokon való részvétel mind a motívumok, mind a tanulási stratégiák terén pozitív hatást mutat. Azok a tanulók, akik tehetséggondozó prog- 
ramokra járnak (minden esetben $\mathrm{p}=0,00)$, magasabb elsajátítási ( $\mathrm{m}=78$ százalékpont $>\mathrm{m}=74$ százalékpont), teljesítménykereső $(\mathrm{m}=68$ százalékpont $>\mathrm{m}=64$ százalékpont) motívumokkal és pozitív önhatékonysággal $(\mathrm{m}=69$ százalékpont $>\mathrm{m}=62$ százalékpont) rendelkeznek, mint azok, akik nem járnak ilyen programokra, ám a szorongás esetében alacsonyabb értékeket mutatnak $(\mathrm{m}=47$ százalékpont $<\mathrm{m}=50$ százalékpont). A stratégiahasználat esetében - a segítségkérés és a halogatás kivételével (ahol nincs szignifikáns különbség) - minden esetben a tehetséggondozó programra járók rendelkeznek magasabb értékekkel, vagyis használják gyakrabban az egyes tanulási stratégiákat.

A sportköri foglalkozások nem mutattak Azok a tanulók, akiknek otthon gyakrabban segítenek a tanulásban, kevésbé tudják nyomon követni saját tanulásukat, és ha nehézségeik vannak, kevésbé tudják szabályozni és kontrollálni azt, ráadásul gyakrabban is halogatnak, mint társaik, akik kevesebb segitséget kapnak otthoni tanulásuk során. Az otthoni segítség a tanulási motivumaikra is negatív hatással van, hiszen jellemezóbb ezekre a tanulókra, hogy a rossz jegy elkerülése miatt tanulnak inkább, szorongóbbak, hajlamosabbak a negatív önértékelésre, valamint jellemzóbb rájuk az általános motiválatlanság is. a tehetséggondozói programoknál tapasztalthoz hasonló mértékü összefüggéseket. A pozitív önhatékonyság kapcsán azok, akik sportköri foglalkozásokra járnak, szignifikánsan $(\mathrm{p}=0,00)$ magasabb értékekkel rendelkeznek ( $\mathrm{m}=67$ százalékpont $>\mathrm{m}=64$ százalékpont), ugyanakkor a stratégiák közül a megszervezés/elaboráció $(\mathrm{m}=50$ százalékpont $>m=47$ százalékpont) és a tervezés $(\mathrm{m}=59$ százalékpont $>\mathrm{m}=56$ százalékpont) terén mutatnak magasabb értékeket.

\section{Összegzés}

Vizsgálatunkban 4. évfolyamos tanulók önszabályozott tanulását, vagyis motívumfejlettségét és stratégiahasználatát vizsgáltuk családi és iskolai környezeti tényezőkkel összefüggésben. Az eredmények alapján a vizsgált tényezők között szignifikáns, de inkább tendenciaszerü összefüggések mutathatók ki. Az otthoni támogatás itemeinek dichotomizálása után a két csoport (támogatják, illetve nem támogatják otthon) között több szignifikáns eltérést találtunk. Kiderült, hogy az önszabályozott tanulás szempontjából leginkább az otthoni, segítség nélküli tanulás jár együtt a kontrolláló, metakognitív stratégiák gyakoribb használatával és a pozitív motívumok fejlettségével. Azok a tanulók tehát, akik segítség nélkül tanulnak, jobban tudják szabályozni, nyomon követni tanulásukat, gyakrabban használják a memorizálást, és jobban bíznak saját képességeikben, valamint tanulásuk során tudásuk, képességeik fejlesztésére törekednek. Ez ugyanakkor fordítva is igaz: azok a tanulók, akik magabiztosabban használják ezeket a stratégiákat, gyakrabban tanulnak segítség nélkül, mint azok, akik bizonytalanabbak ezen stratégiák müködtetésében.

Az is kiderült, hogy az otthoni támogatás jellemzője nagyban befolyásolja azt, hogy az önszabályozott tanulás milyen irányt mutat. Míg a közvetettebb segítségnyújtás („otthon megbeszéljük az iskolában történteket”, „otthon kikérdezik a leckét”) az egyes tanulási stratégiák gyakoribb használatával és a pozitív motívumok fejlettségével jár együtt, a közvetlen, konkrét „,beavatkozást” mutató tényező („otthon segítenek a tanulásban”) éppen az ellenkező hatással párosul. Azok a tanulók, akiknek otthon gyakrabban segítenek a tanulásban, kevésbé tudják nyomon követni saját tanulásukat, és ha nehézségeik 
vannak, kevésbé tudják szabályozni és kontrollálni azt, ráadásul gyakrabban is halogatnak, mint társaik, akik kevesebb segítséget kapnak otthoni tanulásuk során. Az otthoni segítség a tanulási motívumaikra is negatív hatással van, hiszen jellemezőbb ezekre a tanulókra, hogy a rossz jegy elkerülése miatt tanulnak inkább, szorongóbbak, hajlamosabbak a negatív önértékelésre, valamint jellemzőbb rájuk az általános motiválatlanság is. Ezek az eredmények illeszkednek az önszabályozás azon irodalmához, amelyek a szülői kontroll negatív hatását emelik ki az önszabályozásra nézve (Blair és mtsai, 2010; Eisenberg és mtsai, 2010).

Az iskolai környezeti hatások kapcsán hasonló tendencia rajzolódott ki. Az osztályismétlés és a korrepetáláson való részvétel a tanulási stratégiák alacsonyabb szintű használatát és a negatív motívumok magasabb fejlettségét eredményezi. Ezzel szemben a pozitívabb környezeti hatások (tehetséggondozási programon vagy sportköri foglalkozáson való részvétel) jobban elősegítik a tanulási stratégiák használatát és a pozitív motívumok fejlettségét.

Az eredményeink azt mutatják, hogy a 4. évfolyamos tanulókat ért környezeti hatások közül azok segítik leginkább az önszabályozott tanulást, amelyek egyrészt a család részéről a közvetettebb, az önállóságot jobban megengedő, másrészt az iskolai tényezők közül a pozitív, támogató (és nem elmarasztaló) beavatkozások formájában nyilvánulnak meg. Láthattuk, hogy az iskolai történések otthoni megbeszélése, a lecke otthoni kikérdezése (miután már megtanulta a tanuló) fontos a gyerekek számára, hiszen elösegítik a hatékonyabb tanulást. Ezzel együtt az iskolai tehetséggondozási programon, sportköri foglalkozáson való részvétel szintén támogatja a tanulás hatékonyabb kimenetelét. Ha a család és az iskola környezeti hatását együttesen figyelembe vesszük, és a jövőre vonatkozóan megállapításokat teszünk, egyértelműen a támogató, de nem túlzottan kontrolláló magatartás oldalára tevődik a hangsúly. Természetesen leginkább akkor, ha az önálló, önszabályozott tanulás mellett voksolunk.

\section{Köszönetnyilvánítás}

A szerző a tanulmány megírása alatt Bolyai János Kutatási Ösztöndíjban részesült. A vizsgálat sikeres lebonyolítását az SZTE-MTA Képességfejlődés Kutatócsoport munkatársai és infrastruktúrája tette lehetővé.

\section{Irodalomjegyzék}

Allan, D. M., Allan, N. P., Lernera, M. D., Farringtona, A. L. és Lonigana, C. J. (2015): Identifying unique components of preschool children's self-regulatory skills using executive function tasks and continuous performance tests. Early Childhood Research Quarterly, 32. sz. 40-50. DOI: 10.1016/j. ecresq.2015.02.001

Alvi, E. és Gillies, R. M. (2015): Social interactions that support students' self-regulated learning: A case study of one teacher's experiences. International Journal of Educational Research, 72. sz. 14-25. DOI: 10.1016/j.ijer.2015.04.008

Bandura, A. (1986): Social foundations of thought and action: A social cognitive theory. Prentice-Hall, Englewood Cliffs, NJ.

Blair, C. (2002): School readiness: Integrating cognition and emotion in a neurobi-ological conceptualiza- tion of children's functioning at school entry. AmericanPsychologist, 57. sz. 111-127. DOI: 10.1037//0003-066x.57.2.111

Blair, C., Calkins, S. és Kopp, L. (2010): Self-regulation as the interface of emotional and cognitive development: Implications for education and academic achievement. In: Hoyle, R. H. (szerk.): Handbook of personality and self-Regulation. Blackwell Publishing Ltd, United Kingdom. 64-90. DOI: 10.1002/9781444318111

Blair, C. és Razza, R. P. (2007): Relating effortful control, executive function, and false belief understanding to emerging math and literacy abil-ity in kindergarten. Child Development, 78. sz. 647-663. DOI: 10.1111/j.1467-8624.2007.01019.x

Blair, C., Granger, D., Willoughby, M., Mills-Koonce, R., Cox, M., Greenberg, M. T. és FLP Investiga- 
tors (2011): Salivary cortisol mediates effects of povertyand parenting on executive functions in early childhood. Child Development, 82. sz.1970-1984. DOI: 10.1111/j.1467-8624.2011.01643.x

Butler, D. L. (2002): Qualitative approaches to investigating self-regulated learning: Contributions and challenges. Educational Psychologist, 37. 1. sz. 59-63. DOI: 10.1207/00461520252828564

Csapó Benő (2014): A szegedi iskolai longitudinális program. In: Pál József és Vajda Zoltán (szerk.): Szegedi Egyetemi Tudástár 7. Bölcsészet- és társadalomtudományok. Szegedi Egyetemi Kiadó, Szeged. $117-166$

Csíkos Csaba (2007): Metakognició - A tudásra vonatkozó tudás pedagógiája. Müszaki Könyvkiadó, Budapest.

D. Molnár Éva (2013): Tudatos fejlödés. Az önszabályozott tanulás elmélete és gyakorlata. Akadémiai Kiadó, Budapest.

Deci, E. L. és Moller, A. C. (2007): 'The Concept of Competence: A Starting Place for Understanding Intrinsic Motivation and Self-Determinated Extrinsic Motivation'. In: Elliot, A. J. és Dweck, C. S. (szerk.): Handbook of Competence and Motivation. The Guilford Press, New York. 579-598.

Dweck, C. és Master, A. (2008): Self-theories motivate self-regulated learning. In: Schunk, D. H. és Zimmerman, B. J. (szerk.): Motivation and self-regulated learning: Theory, research, and applications. 2nd ed. Lawrence Erlbaum Associates Publishers, New York - London. 31-52. DOI: 10.4324/9780203831076

Eisenberg, N., Eggum, N. D., Sallquist, J. és Edwards, A. (2010): Relations of self-regulatory/ control capacities to maladjustment, social competence, and emotionality. In: Hoyle, R. H. (szerk.): Handbook of Personality and Self-Regulation. Blackwell Publishing Ltd., United Kingdom. 21-46. DOI: 10.1002/9781444318111

Eisenberg, N., Eggum, N. D., Sallquist, J. és Edwards, A. (2010): Relations of self-regulatory/ control capacities to maladjustment, social competence, and emotionality. In: Hoyle, R. H. (szerk.): Handbook of Personality and Self-Regulation. Blackwell Publishing Ltd., United Kingdom. 21-46. DOI: 10.1002/9781444318111

Evans, G. W. és Schamberg, M. A. (2009): Childhood poverty, chronic stress, and adultworking memory. Proceedings of the National Academy of Sciences of the United States of America, 106. sz. 6545-6549. DOI: 10.1073/pnas.0811910106

Fejes József Balázs (2011): A célorientációs elmélet lehetőségei a tanulási motiváció kutatásában. Magyar Pedagógia, 111. 1. sz. 25-51.

Garcia, T. és Pintrich, P. R. (1994): Regulating motivation and cognition in the classroom: The role of self-schemas and self-regulatory strategies. In: Schunk, H. D. és Zimmerman, B. J. (szerk.): Self-re- gulation of learning and performance. Lawrence Erlbaum, Hillsdale. 127-155.

Grolnick, W. S. (2009): The role of parents in facilitating autonomous self-regulation for education. Theory and Research in Education, 7. 2. sz. 164-173. DOI: $10.1177 / 1477878509104321$

Guinote, A. (2007): Power and goal pursuit. Personality and Social Psychology Bulletin, 33. 8. sz. 10761087. DOI: $10.1177 / 0146167207301011$

Hidi, S. és Ainley, M. (2008): lnterest and self-regulation: Relationships between two variables that influence learning. In: Schunk, D. H. és Zimmerman, B. J. (szerk.): Motivation and self-regulated learning. Theory, research, and applications. 2nd ed. Lawrence Erlbaum Associates Publishers, New York - London. 77-109. DOI: $10.4324 / 9780203831076$

Higgins, E. T. és Silberman, I. (1998): Development of regulatory focus: Promotion and prevention as ways of living. In: Heckhausen, J. és Dweck, C. S. (szerk.): Motivation and self-regulation across the life span. Cambridge University Press, New York. 78-114. DOI: 10.1017/cbo9780511527869

Jennings, K. D., Sandberg, I., Kelley, S. A., Valdes, L., Yaggi, K., Abrew, A. és Macey-Kalcevic, M. (2008): Understanding of self and maternal warmth predict later self-regulation in toddlers. International Journal of Behavioral Development, 32. 2. sz. 108 118. DOI: $10.1177 / 0165025407087209$

Józsa Krisztián, Szenczi Beáta és Hricsovinyi Julianna (2011): A tanulási motiváció számítógép-alapú mérési lehetőségei. In: Csapó Benő és Zsolnai Anikó (szerk.): Kognitiv és affektív fejlödési folyamatok diagnosztikus értékelésének lehetöségei az iskola kezdő szakaszában. Nemzeti Tankönyvkiadó, Budapest. 147-171.

Kochanska, G., Murray, K. T. és Harlan, E. T. (2000): Effortful controlin early childhood: Continuity and change, antecedents, and implications for social development. Developmental Psychology, 36. sz. 220 232. DOI: $10.1037 / 0012-1649.36 .2 .220$

Linnenbrink, E. A. és Pintrich, P. R. (2001): Multiple goals, multiple contexts: The dynamic interplay between personal goals and contextual goal stresses. In: Volet, S. és Järvelä, S. (szerk.): Motivation in learning contexts: Theoretical advances and methodological implications. Elsevier, New York. 251-269.

Nagy József (2000): XXI. század és nevelés. Osiris Kiadó, Budapest.

Pajares, F. (2008): Motivational role of self-efficacy beliefs in self-regulated learning. In: Schunk, D. H. és Zimmerman, B. J. (szerk.): Motivation and self-regulated learning: Theory, research, and applications. 2nd ed. Lawrence Erlbaum Associates Publishers, New York - London. 111-140. DOI: 10.4324/9780203831076

Perry, N. E., Thauberger, C. és Hutchinson, L. (2010): Study traces of children's self-regulated learning in 
the Lifecycles Learning Kit. Psychological Test and Assessment Modeling, 52. 4. sz. 432-453.

Posner, M. I. és Rothbart, M. K. (2000): Developing mechanisms of self-regulation. Development and Psychopathology, 12. sz. 427-441. DOI: $10.1017 /$ s0954579400003096

Rimm-Kaufman, S. E., Curby, T. W., Grimm, K. J., Nathanson, L. és Brock, L. L. (2009): The contribution of children's self-regulation and classroom quality to children's adaptive behaviors in the kindergarten classroom. Developmental Psychology, 45. sz. 958-972. DOI: 10.1037/a0015861

Rothbart, M. K. és Bates, J. E. (2006). Temperament in children's development. In: Damon, W., Lerner, R. és Eisenberg, N. (szerk.): Handbook of child psychology. Vol. 3. Social, emotional, and personality development. 6th ed. Wiley, New York. 99-166. DOI: 10.1002/9780470147658

Schraw, G., Crippen, K. J. és Hartley, K. (2006): Promoting self-regulation in science education: Metacognition as part of a broader perspective on learning. Research in Science Education, 36. sz. 111-139. DOI: $10.1007 / \mathrm{s} 11165-005-3917-8$

Soric, I. (2009): Regulatory Styles, Causal Attributions and Academic Achievement. School Psychology International, 30. 4. sz. 403-420. DOI: $10.1177 / 0143034309106946$
Tyson, P. (2004): Affects, agency, and self-regulation: Complexity theory in the treatment of children with anxiety and disruptive behavior disorders. Journal of the American Psychoanalytic Association, 53. 159187. DOI: $10.1177 / 00030651050530012201$

Whitebread, D., Anderson, H., Coltman, P., Page, C., Pino Pasternak, D. és Mehta, S. (2005): Developing independent learning in the early years. Education $3-13$, 33. 1. sz. 40-50. DOI: 10.1080/03004270585200081

Winne, P. H. és Perry, N. E. (2000): Measuring self-regulated learning. In: Boekaerts, M., Pintrich, P. R. és Zeidner, M. (szerk.): Handbook of Self-Regulation. Academic Press, San Diego. 532-567.

Zimmerman, B. (1989): A social cognitive view of self-regulated learning. Journal of Educational Psychology, 81. 329-339. DOI: 10.1037/00220663.81.3.329

Zimmerman, B. J. (2000): Attaining self-regulation: A social cognitive perspective. In: Boekaerts, M., Pintrich, P. R. és Zeidner, M. (szerk.): Handbook of Self-Regulation. Academic Press, San Diego. 13-42.

Zimmerman, B. J. (2008). Investigating self-regulation and motivation: Historical background, methodological developments, and future prospects. American Educational Research Journal, 45. 1. sz. 166-183. 